in vivo $33: 1051-1058$ (2019)

doi:10.21873/invivo.11573

Review

\title{
Pharmacogenetic Implications of eNOS Polymorphisms (Glu298Asp, T786C, 4b/4a) in Cardiovascular Drug Therapy
}

\author{
ANGELA COZMA ${ }^{1,2^{*}}$, ADRIANA FODOR ${ }^{1,3^{*}}$, OLGA HILDA ORASAN ${ }^{1,2^{*}}$, \\ ROMANA VULTURAR ${ }^{1,4}$, DOREL SAMPLELEAN ${ }^{1,2}$, VASILE NEGREAN $^{1,2}$, \\ CRINA MURESAN ${ }^{5}$, RAMONA SUHAROSCHI ${ }^{5}$ and ADELA SITAR-TAUT ${ }^{1,2}$ \\ ${ }^{1}$ University of Medicine and Pharmacy "Iuliu Hatieganu”, Cluj-Napoca, Romania; \\ ${ }^{2} 4$ th Internal Medicine Department, University of Medicine and Pharmacy “Iuliu Hatieganu”, Cluj-Napoca, Romania; \\ ${ }^{3}$ Clinical Center of Diabetes, Nutrition and Metabolic Disease, Cluj-Napoca, Romania; \\ ${ }^{4}$ Department of Cell Biology, University of Medicine and Pharmacy “Iuliu Hatieganu”, Cluj-Napoca, Romania; \\ ${ }^{5}$ University of Agricultural Sciences and Veterinary Medicine of Cluj-Napoca, \\ Faculty of Food Science \&Technology, Cluj-Napoca, Romania
}

\begin{abstract}
Endothelial nitric oxide synthase (NOS3 or eNOS) is the enzyme responsible for the highest production of nitric oxide, with the greatest impact on the cardiovascular system, encoded by the eNOS gene, which presents various polymorphisms. ENOS gene polymorphisms play an important role in the response to drugs affecting nitric oxide (NO) signaling. This review discusses the pharmacogenetic impact of eNOS polymorphisms on the response to drugs affecting NO activity: angiotensin converting enzyme inhibitors, angiotensin II receptor antagonists, calcium blockers, beta-blockers, diuretics, phosphodiesterase inhibitors, and statins. The identification of biomarkers that accurately predict particular phenotypes is a challenge that needs additional large studies, in different populations. Efforts should be oriented towards a more accurate evaluation of the effects of eNOS genetic variants on biochemical parameters reflecting eNOS gene expression and enzymatic activity, in different diseases, as well as following drug treatment. This approach will allow for a better understanding of the role of eNOS genetic variants in
\end{abstract}

This article is freely accessible online.

*These Authors contributed equally to this work.

Correspondence to: Ramona Suharoschi, Faculty of Food Science \& Technology, University of Agricultural Sciences and Veterinary Medicine of Cluj-Napoca, Manastur Street, No 3-5, 400000 ClujNapoca, Romania. Tel: +40 730630252,e-mail: ramona.suharoschi@ usamvcluj.ro

Key Words: Cardiovascular drug, eNOS, pharmacogenetics, polymorphisms, nitric oxide, review. cardiovascular disease progression and for cardiovascular drug therapy optimization.

Lack of a positive response to drugs or a toxic reaction to usual doses are responsible for high morbidity and mortality rates and for increasing health care costs $(1,2)$. The variability of patients' response can be explained by pharmacogenetics, an interdisciplinary field combining pharmacological and genetic information, which addresses how genetic polymorphisms may influence the response or lack of response to different classes of drugs, as well as the development of various degrees of toxicity $(1,3)$. Previous studies have showed that $20-95 \%$ of the variation in individual drug responses can be explained by genetic polymorphisms (4).

In the cardiovascular field, the response to administrated medications is influenced by many factors, such as doses, patient's disease and particularities (dyslipidemia, hypertension, atherosclerotic diseases, genetic polymorphism) (5-7).

Endothelial dysfunction represents one of the first steps of atherosclerosis, which develops even before any angiographic evidence of disease. One basic characteristic of this dysfunction involves the alteration of nitric oxide (NO) synthesis, release and activity (8).

The production of NO is mediated by the endothelial nitric oxide synthase (eNOS) $(9,10)$ from L-arginine by NOS (neuronal, endothelial and inducible) (10). Decreased NO synthesis results in the development of cardiovascular diseases, responsible for the increased number of deaths worldwide (11). Various eNOS gene polymorphisms have been described (10), such as insertions/deletions, microsatellites, single nucleotide polymorphisms (SNPs), and variable number of tandem repeats (VNTRs). 
NO signaling can be modulated by different drugs, and their effect may be influenced by eNOS gene polymorphism (1218). Despite being constitutively expressed, eNOS is regulated by many stimuli at transcriptional, posttranscriptional and posttranslational level (19). In this regard, variations in the eNOS gene influence its activity, which consequently affects NO production (20).

NO plays an important role in the normal physiology of the cardiovascular system, and dysfunctional NO signaling has been associated with development and progression of cardiovascular diseases - myocardial infarction, coronary spasm, intra-stent thrombosis, heart failure (21-25, 26-31).

The following eNOS gene polymorphisms, as the most extensively studied, will be described here: i) G894T (Glu 298Asp), exon 7 (rs1799983), ii) T786C, promoter SNP (rs2070744), and iii) Intron 4 (4b/4a), VNTR.

The single nucleotide polymorphism, rs 1799983 is located in exon 7, position 894 in the NOS3 gene (G894T) and determines a glutamine to aspartate change at position 298 of the protein (Glu298Asp) (32). The variant allele for G894T polymorphism reduces eNOS binding to caveolin-1, leading to eNOS diminished availability and activity in endothelial cells (33). The presence of reduced NO formation in patients with this allelic variant supports these in vitro findings (34, 35). At a transcriptional level, eNOS can be affected by a single nucleotide polymorphism, rs2070744 (T786C), which dramatically reduces ENOS transcriptional activity $(36,37)$. This effect is linked to replication protein A1 (RPA1), which binds to the eNOS promoter with higher affinity in the presence of the mutation (38). In fact, inhibition of RPA1 expression can restore the transcriptional activity in the eNOS promoter with the $\mathrm{C}$ allele, whereas RPA1 over-expression has the contrary effect (38). Interestingly, these in vitro studies are consistent with in vivo changes, which have shown that the circulating levels of NO-related markers in subjects carrying the $\mathrm{C}$ allele tend to be lower (16) compared to that of $\mathrm{T}$ allele carriers, supporting a functional importance of this polymorphism (38).

The $4 b / 4 a V N T R$ polymorphism in intron 4 (variable number of tandem repeats on intron 4) of the eNOS gene regulates eNOS post transcriptionally, by altering the formation of a small interfering RNA (siRNA) (39). The types of this polymorphism with four (variant $4 \mathrm{a}$ ) or five copies (variant $4 \mathrm{~b}$ ) of the 27 bp siRNA fragment (20) are the most commonly met alleles. In vitro studies have shown higher siRNA levels in endothelial cells containing five copies, determining lower eNOS mRNA levels, compared to cells containing only four copies $(39,40)$.

Correlations between eNOS gene polymorphisms and differentiated responses to cardiovascular drugs have also been reported (41). In this review we discuss the pharmacogenetic impact of eNOS polymorphisms on drugs that affect eNOS activity, such as antihypertensive drugs with a role in NO bioavailability. These include: i) angiotensin converting enzyme inhibitors, ii) angiotensin II receptor antagonists, iii) calcium blockers, iv) beta-blockers, v) diuretics, and other drugs whose action is influenced by nitric oxide, such as phosphodiesterase inhibitors and statins.

\section{Angiotensin-converting Enzyme Inhibitors}

Antihypertensive drugs' effects are influenced by ENOS polymorphism $(14,18)$. Angiotensin-converting enzyme (ACE) inhibitors are among the most used antihypertensive drugs (42). ACE inhibition is responsible for vasodilation and improvement of endothelial function, through decreasing the levels of angiotensin II and increasing those of bradykinin (43). Bradykinin stimulates endothelial cell receptors, leading to eNOS activation, NO release and vasodilation (44).

Silva et al., showed in a study on hypertensive patients treated with enalapril (an ACE inhibitor), that the " $C$ " alleles of the rs2070744 polymorphism were more frequently found in patients with a good response to Enalapril (18). On the other hand, the same group has also shown that there were no differences between responders and non-responders to enalapril when they beared the $4 b / 4 a$ and Glu298Asp alleles of the eNOS polymorphism (18).

Sandrim et al., reported that the "C Glu b" haplotype is more frequently found in NT (normotensive healthy controls) compared to HT (hypertensive patients) or RHT (resistant hypertensive patients) (NT 21\% versus HT 8\% and RHT 7\%, both $p<0.00625)$ (45). In HT or the RHT groups, the "C Asp b" haplotype was more frequently found (HT 22\% and RHT $20 \%$, versus NT $8 \%$, both $p<0.00625$ ) (45). According to this study, no significant difference was found between HT and RHT patients regarding distribution of eNOS haplotypes in the HT and RHT groups, suggesting an inconsequential influence of the eNOS gene on the antihypertensive therapy's resistance.

Oliveira-Paula et al., (46) also reported that GG genotype for rs 16960228 polymorphism of the PRKCA influenced the quality of enalapril response. In a recent review, Luizon et al. (47), showed that eNOS polymorphisms are associated with susceptibility of preeclampsia (PE) and affect the response to antihypertensive treatment in PE. In fact, eNOS haplotypes combining the "C, a, Glu" of the T-786C (rs2070744), 27 bp VNTR a/b and Glu298Asp (rs1799983) were more frequent in the responsive subgroup of $\mathrm{PE}$ to antihypertensive treatment (47).

\section{Angiotensin II Receptor Blockers (ARBs)}

Clinical studies have confirmed a significant amelioration of the endothelium-dependent vasodilation in patients with arterial hypertension treated with angiotensin II receptor 
blockers (ARBs) compared to placebo or other antihypertensive agents (48-51). The increased NO release from the ARB therapy can be pharmacologically explained by the reduced activity of angiotensin II, resulting in enhanced antioxidant protection and NO bioavailability $(52$, 53). Even though bradykinin concentration is not increased by $A R B s$, the latter can induce eNOS expression (54-56). Mason et al., (55) have reported higher endothelial NO release induced by all the tested ARBs (losartan, olmesartan, telmisartan, valsartan) compared to untreated cells. Different ARBs affect the NO release in various ways, depending on eNOS polymorphisms. Olmesartan (55) can raise NO levels by approximately $30 \%$ in different eNOS genotypic backgrounds, with the most evident difference in ECs from donors homozygous for the nucleotide mutations $T-786 C$ and G894T. This result shows the specific effects of ARBs on eNOS function, which is in turn influenced by single nucleotide substitution, followed by changes in NO metabolism and finally leading to augmented cardiovascular risk, including hypertension (57-62). The relative contribution of the different mutations to ARB responses requires a separate thorough study.

\section{Beta-blockers}

Liljedahl et al., have demonstrated that the G allele of the $2996 A / G$ eNOS polymorphism is associated with a higher blood pressure (BP) response to a $\beta$-blocker, and the A allele of the 498G/A eNOS polymorphism is associated with higher $\mathrm{BP}$ responses to a $\beta$-blocker and an angiotensin II receptor blocker (63).

Pacanowski et al., have shown that patients with eNOS polymorphisms have relatively lower BP during treatment and enhanced rates of BP control (64). Although this correlation was important only for patients assigned to the verapamil SR strategy, a similar tendency appeared when alternative treatment using atenolol was administered. Thus, aggressive multi-drug regimens used in INVEST (International Verapamil SR/Trandolapril Study) (65), irrespective of the drug types included, may induce a superior therapeutic response in patients with the $-786 T>C$ polymorphism. INVEST was a prospective, randomized trial comparing antihypertensive therapy with $\beta$-blockers versus calcium antagonists in 22,576 CAD (coronary artery disease) patients with hypertension (65). The accurate mechanism of the stronger association observed in subjects treated with verapamil is not known.

Interestingly, in agreement with prior evidence, this result supports the fact that atenolol does not influence endothelial function or alteration of NO biodisponibility (66-67). A difference of 4-7 $\mathrm{mmHg}$ in BP across the different genotype groups in the verapamil SR arm is a clinically significant variation, knowing the fact that a constant reduction of 12
$\mathrm{mmHg}$ in systolic BP prevents one death for every 11 patients treated (68). There is no consistent association of eNOS polymorphisms with BP phenotypes (69-71). These results suggest that eNOS genotype might contribute to heterogeneity of responses to several antihypertensive drugs, and pharmacogenetic studies should pursue a more complete characterization of this biologically plausible polymorphism drug relationship.

\section{Calcium Blockers}

Several calcium blockers, such as nifedipine, have shown to improve both endothelial function and NO bioavailability (72-73). According to previous studies, amlodipine (a calcium blocker) may provoke vasodilation through eNOS activation (74). At least one of the pathways in eNOS activation is known to be calcium-dependent (72-73). Amlodipine blocks $\mathrm{Ca}$ efflux, deactivating eNOS through regulation of $\mathrm{Ca}$. In a randomized clinical trial, Zhang et al., reported that for rs1799983 (Glu298Asp G>T), lower allcause mortality was observed in minor allele carriers treated with amlodipine versus lisinopril [for $\mathrm{GG} \quad \mathrm{HR}=1.01$ $(95 \% \mathrm{CI}=0.91-1.13), \quad \mathrm{GT}+\mathrm{TT}=0.85 \quad(95 \% \mathrm{CI}=0.75-0.97)$, $p=0.04]$ (75). The authors also showed significant associations between eNOS variants with CHD and heart failure as well as significant pharmacogenetic effects for stroke and all-cause mortality. This suggests the fact that eNOS3 polymorphisms might give practical information with regard to treatment choosing decisions in the future.

\section{Diuretics}

Thiazide diuretics are extensively used for hypertension control, with hydrochlorothiazide (HCTZ) being the most used in the clinical practice (76). It has been established that the Glu298Asp polymorphism in the eNOS gene is capable to modulate the response to hydrochlorothiazide, thus subjects homozygous for the Glu allele have a significantly greater reduction in BP levels compared to individuals with the Asp allele (76). Despite having a significant effect, it is rather is small, demonstrating that, for a single polymorphism, it is difficult to explain the entire genetic background underlying variations in the pharmacological responses of a medication class.

\section{Phosphodiesterase Type 5 (PDE-5) Inhibitors}

eNOS polymorphisms also influence the treatment of erectile dysfunction (ED) $(15,77)$. Phosphodiesterase type 5 (PDE$5)$ inhibitors are commonly used for the treatment of ED since inhibition of the PDE-5 enzyme increases the tissue cGMP concentration, mainly in the absence of NO signaling (77). Eisenhardt et al., have shown that homozygous subjects 
for the "Asp" allele of the Glu298Asp eNOS polymorphism are less responsive to sildenafil (an PDE-5 inhibitor) (13), however, this association is still subject to controversy (13, 15). Patients with ED carrying the " $4 \mathrm{a}$ " and " $\mathrm{C}$ " alleles show enhanced responses to sildenafil versus the " $4 \mathrm{~b}$ " and " $\mathrm{T}$ " alleles for the $4 b / 4 a$ VNTR and $g .-786 T>C$ eNOS polymorphisms, respectively $(13,15)$. Muniz et al., have reported that reduced plasma nitrite concentration predicts better responses to sildenafil. In addition, response to sildenafil is influenced by eNOS haplotypes including $g$.786T>C, Glu298Asp and 4b/4a VNTR (15).

Lacchini et al., have demonstrated that the "T" allele of the Glu298Asp eNOS polymorphism, the " $4 \mathrm{~b}$ " allele of the $4 b / 4 a$ VNTR and the "C" allele $(T 786>C)$ are associated with a poor response to therapy with PDE-5 inhibitors (77).

In a recent study by Di Salvatore et al., the role of eNOS polymorphism in the development of hypertension and proteinuria was presented, by associating the eNOS $c .-894 T$ genotype with a significantly higher rate of grade 3-4 hypertension and proteinuria $(p=0.0002)(78)$.

In this context, carriers of the "T" allele of $c .-894 T$ eNOS polymorphism that show lower basal eNOS levels may have increased risk of hypertension induced by VEGF blockade (79-81).

\section{Statins}

The main effects of statins are due to the decrease in cholesterol synthesis (8), through blocking of the conversion of 3-hydroxy3-methylglutaryl coenzyme A (HMG-CoA) to mevalonate (8, $10,82-83$ ), independent of eNOS polymorphisms.

At the same time, as it has previously been suggested (10, 41) that statins' effects and eNOS polymorphisms modulate each other in a reciprocal way. The decrease in serum cholesterol can also cause an increase in endothelial nitric oxide production $(8,82,84)$ and improve endothelial function (8), even before a significant decrease in serum cholesterol occurs (85-89).

Statins can affect eNOS regulation at the transcriptional and posttranscriptional level (90). Studies have shown that fluvastatin and atorvastatin can increase the transcriptional activity of the eNOS gene. Statins can also inhibit the replication protein A1 (RPA1), a repressor of the transcriptional activity of eNOS $(1,16,41)$, particularly in subjects with the CC genotype $(1,12,38,91)$. This has been demonstrated by increased circulating levels of nitric oxide biomarkers (nitrite and nitrate) following administration of statins, regardless of the genotype, but being higher in C-allele carriers $(1,12,16$, $41,82,83)$. Such effects have been reported in hypertensive (92), dyslipidaemic subjects (93) and obese women (83) so far.

Statins can also increase eNOS expression and activity compensating the genetic disadvantage of subjects with the CC genotype for the $T 786 C$ polymorphism - $(1,10,16,41$,
94-98), effect on eNOS expression not being lowered when LDL cholesterol values normalized (94).

Statins play an additional role in eNOS function by decreasing the level and inhibitory activity of caveolin (99, 100). In patients with the eNOS Glu298Asp mutation (guanine to thymine conversion at position 894 of the gene), the mutant endothelial cells seem to produce less NO, reducing the availability of eNOS in the caveolae of these cells (41).

Statins inhibit isoprenoids, small GTP-binding proteins, Rho (which induces an increase in vascular smooth muscle sensitivity to calcium), Ras, and Rac (its activation leads to the formation of lamellipodia and membrane ruffles) $(8,89)$. Therefore, statins cause an accumulation of inactive Ras and Rho in the cytoplasm $(8,89)$ and increase eNOS expression (101) and eNOS mRNA stability $(8,55,94)$, thus prolonging the eNOS mRNA half-life (101).

Statins also bear antioxidant properties, particularly in the CC genotype $(1,8,16,83)$. They decrease different markers of atherosclerosis $(8,82)$, the anti-inflammatory effect being modulated by eNOS polymorphism $(1,16,41,82-83)$. This idea was demonstrated by a study using atorvastatin, which significantly reduced sCD40L, sVCAM-1, sP-selectin and MMP-9 concentrations only in subjects with the $\mathrm{CC}$ genotype $(41,82)$.

Statins are capable of reducing the fluidity of the red blood cell plasma membrane, but only in the case of the $\mathrm{CC}$ genotype for the T786C polymorphism $(41,82)$.

Stains' modulation on the eNOS system is influenced by the polymorphism in intron 4. Adenosine-induced coronary vasodilation was assessed by Kunnas in healthy individuals (treated with pravastatin). Individuals with the "a" allele of the $4 b / 4 a$ VNTR show a significant enhancement in vasodilation compared to individuals with the "bb" genotype, possibly due to a greater raise in endothelial NO production (102).

All these mechanisms seem to support the idea that statins are more useful in preventing cardiovascular diseases, by countering the mechanisms underlying the development of cardiovascular diseases, particularly in subjects with the CC genotype $(1,41)$.

\section{Conclusion}

Further studies are needed to elucidate the functional and clinical implications of eNOS3 polymorphism. The finding of biomarkers able of predicting a particular phenotype with accuracy is a challenge that will probably involve large scale studies, with results applicable in different populations.

Efforts should be oriented towards an evaluation of the effects of NOS3 genetic variants on biochemical parameters reflecting eNOS gene expression and enzymatic activity (in patients developing different pathologies). This approach can permit progress in our understanding of how eNOS genetics 
may contribute to cardiovascular disease and help us optimize the relevant drug therapy.

We propose a change in treatment paradigm, from an approach based on average effects (reported in large cohorts) to individualized treatment to revolutionize both patients' therapy and manage adverse health effects, especially for cardiovascular disease patients.

\section{Conflicts of Interest}

The Authors declare that there are no conflicts of interest.

\section{Authors' Contributions}

All the Authors contributed to the conception and design of the article and approved the final version submitted for publication.

\section{References}

1 Lacchini R, Silva PS and Tanus-Santos JE: A pharmacogeneticsbased approach to reduce cardiovascular mortality with the prophylactic use of statins. Basic Clin Pharmacol Toxicol 106: 357-361, 2010. PMID: 20210789. DOI: 10.1111/j.1742-7843. 2010.00551.x

2 Haga SB and LaPointe NM:The potential impact of pharmacogenetic testing on medication adherence. Pharm J 13: 481-483, 2013. PMID 23999596. DOI: 10.1038/tpj.2013.33

3 Evans WE and McLeod HL: Pharmacogenomics-drug disposition, drug targets, and side effects. N Engl J Med 348: 538-549, 2003. PMID: 12571262. DOI: 10.1056/NEJMra020526

4 Wang L, McLeod HL and Weinshilboum RM: Genomics and drug response. N Engl J Med 364: 1144-1153, 2011. PMID: 21428770. DOI: $10.1056 /$ NEJMra 1010600

5 Li H, Wallerath T, Münzel T and Förstermann U: Regulation of endothelial-type NO synthase expression in pathophysiology and in response to drugs. Nitric Oxide 7(3): 149-164, 2002. PMID: 12381413.

6 Fodor A, Cozma A and Karnieli E:TBC update: personalized epigenetic management of diabetes. Per Me 14(6): 531-549, 2017. PMID: 29749858. DOI: 10.2217/pme-2017-0043

7 Campedelli FL, Silva KSF, Rodrigues DA, Martins JVM, Costa IR, Lagares MH, Barbosa AM, de Morais MP and Moura KKVO: Polymorphism of the gene eNOS G894T (Glu298Asp) in symptomatic patients with aterosclerosis. Genetd Mol Res 16(2), 2017. PMID: 28481400. DOI: $10.4238 /$ gmr 16029550

8 Liao JK and Laufs U: Pleiotropic effects of statins. Annu Rev Pharmacol Toxicol 45: 89-118, 2005. PMID: 15822172. DOI: 10.1146/annurev.pharmtox.45.120403.095748

9 Godo S and Shimokawa H: Divergent roles of endothelial nitric oxide synthases system in maintaining cardiovascular homeostasis. Free Radic Biol Med 109: 4-10, 2017. PMID: 27988339. DOI: $10.1016 / j$.freeradbiomed.2016.12.019

10 Oliveira-Paula GH, Lacchini R and Tanus-Santos JE: Clinical and pharmacogenetic impact of endothelial nitric oxide synthase polymorphisms on cardiovascular diseases. Nitric Oxide 63: 3951, 2017. PMID: 27569446. DOI: 10.1016/j.niox.2016.08.004

11 Pagidipati NJ and Gaziano TA: Estimating deaths from cardiovascular disease: a review of global methodologies of mortality measurement. Circulation 127: 749-756, 2013. PMID: 23401116. DOI: 10.1161/CIRCULATIONAHA.112.128413

12 Abe K, Nakayama M, Yoshimura M, Nakamura S, Ito T, Yamamuro M, Sakamoto T, Miyamoto Y, Yoshimasa Y and Saito Y: Increase in the transcriptional activity of the endothelial nitric oxide synthase gene with fluvastatin: a relation with the 786TNC polymorphism. Pharmacogenet Genomics 15: 329-336, 2005. PMID: 15864134.

13 Eisenhardt A, Sperling H, Hauck E, Porst H, Stief C, Rubben H, Muller N and Siffert W: ACE gene I/D and NOS3 G894T polymorphisms and response to sildenafil in men with erectile dysfunction. Urology 62: 152-157, 2003. PMID: 12837457. DOI: 10.1016/S0090-4295(03)00137-7

14 Mason RP, Jacob RF, Kubant R, Jacoby A, Louka F, Corbalan JJ and Malinski T: Effects of angiotensin receptor blockers on endothelial nitric oxide release: the role of eNOS variants. Br J Clin Pharmacol 74: 141-146, 2012. PMID: 22283728. DOI: 10.1111/j.1365-2125.2012.04189.x

15 Muniz JJ, Lacchini R, Rinaldi TO, Nobre YT, Cologna AJ, Martins AC and Tanus-Santos JE: Endothelial nitric oxide synthase genotypes and haplotypes modify the responses to sildenafil in patients with erectile dysfunction. Pharm J 13: 189196, 2013. PMID: 22064666. DOI: 10.1038/tpj.2011.49

16 Nagassaki S, Sertorio JT, Metzger IF, Bem AF, Rocha JB and Tanus-Santos JE: ENOS gene T-786C polymorphism modulates atorvastatin-induced increase in blood nitrite. Free Radic Biol Med 41: 1044-1049, 2006. PMID: 16962929. DOI: 10.1016/ j.freeradbiomed.2006.04.026

17 Peskircioglu L, Atac FB, Erdem SR, Deveci S, Verdi H and Ozkardes H: The association between intron 4 VNTR, E298A and IVF $23+10 \mathrm{G} / \mathrm{T}$ polymorphisms of ecNOS gene and sildenafil responsiveness in patients with erectile dysfunction. Int J Impot Res 19: 149-153, 2007. PMID: 16871271. DOI: 10.1038/sj.ijir.3901501

18 Silva PS, Fontana V, Luizon MR, Lacchini R, Silva JrWA, Biagi $\mathrm{C}$ and Tanus-Santos JE: ENOS and BDKRB2 genotypes affect the antihypertensive responses to enalapril. Eur J Clin Pharmacol 69: 167-177, 2013. PMID: 22706620. DOI: 10.1007/s00228-0121326-2

19 Rafikov R, Fonseca FV, Kumar S, Pardo D, Darragh C, Elms S, Fulton D and Black SM: ENOS activation and NO function: structural motifs responsible for the posttranslational control of endothelial nitric oxide synthase activity. J Endocrinol 210: 271284, 2011. PMID: 21642378. DOI: 10.1530/JOE-11-0083

20 Cooke GE, Doshi A and Binkley PF: Endothelial nitric oxide synthase gene: prospects for treatment of heart disease. Pharmacogenomics 8: 1723-1734, 2007. PMID: 18086002. DOI: 10.2217/14622416.8.12.1723

21 Moncada S and Higgs EA: Nitric oxide and the vascular endothelium. Handb Exp Pharmacol (176 Pt 1): 213-254, 2006. PMID: 16999221.

22 Pacher P, Beckman JS and Liaudet L: Nitric oxide and peroxynitrite in health and disease. Physiol Rev 87: 315-424, 2007. PMID: 17237348. DOI: 10.1152/physrev.00029.2006

23 Vanhoutte PM: How we learned to say NO. Arterioscler Thromb Vasc Biol 29: 1156-1160, 2009. PMID: 19605779. DOI: 10.1161/ ATVBAHA.109.190215

24 Vanhoutte PM, Shimokawa H, Tang EH and Feletou M: Endothelial dysfunctionand vascular disease. Acta Physiol 196: 193-222, 2009. PMID: 19220204. DOI: 10.1111/j.17481716.2009.01964.x 
25 Zhao Y, Vanhoutte PM and Leung SW: Vascular nitric oxide: Beyond eNOS. J Pharmacol Sci 129: 83-94, 2015. PMID: 26499181. DOI: 10.1016/j.jphs.2015.09.002

26 McNamara DM, Holubkov R, Postava L and Ramani R: Effect of the Asp298 variant of endothelial nitric oxide synthase on survival for patients with congestive heart failure. Circulation 107: 1598-1602, 2003. PMID: 12668492. DOI: 10.1161/01.CIR. 0000060540.93836.AA

27 Paradossi U, Ciofini E, Clerico A and Botto N: Endothelial function and carotid intima-media thickness in young healthy subjects among endothelial nitric oxide synthase Glu298-->Asp and T-786-->C polymorphisms. Stroke 35: 1305-1309, 2004. PMID: 15073390. DOI: 10.1161/01.STR.0000126482.86708.37

28 Yoshimura T, Hisatomi A, Kajihara S and Yasutake T: The relationship between insulin resistance and polymorphisms of the endothelial nitric oxide synthase gene in patients with coronary artery disease. J. Atheroscler Thromb 10: 43-47, 2003. PMID: 12621164. DOI: $10.5551 /$ jat. 10.43

29 Lüscher TF and Noll G: Is it all in genes....? Nitric oxide synthase and coronary vasospasm. Circulation 99: 2855-2857, 1999. PMID: 10359726.

30 Gomma AH, Elrayess MA, Knight CJ and Hawe E: The endothelial nitric oxide synthase (Glu298Asp and -786T $>$ C) gene polymorphisms are associated with coronary in-stent restenosis. Eur Heart J 23: 1955-1962, 2002. PMID: 12473258. DOI: 10.1053/euhj.2002.3400

31 Barbosa AM, Silva KSF, Lageres MH, Rodrigues DA, Da Costa IR, Morais MP, Martins JVM, Mascarenhas RS, Campedelli FL and Moura KKVO: Atherosclerosis: analysis of the eNOS (T786C) gene polymorphism. Genet Molr Res 16(3), 2017. PMID: 28973724. DOI: $10.4238 / \mathrm{gmr} 16039708$

32 Marsden PA, Heng HH, Scherer SW, Stewart RJ, Hall AV, Shi XM, Tsui LC and Schappert KT: Structure and chromosomal localization of the human constitutive endothelial nitric oxide synthase gene. J Biol Chem 268: 17478-17488, 1993. PMID: 7688726.

33 Joshi MS, Mineo C, Shaul PW and Bauer JA: Biochemical consequences of the NOS3 Glu298Asp variation in human endothelium: altered caveolar localization and impaired response to shear. FASEB J 21: 2655-2663, 2007. PMID: 17449720. DOI: 10.1096/fj.06-7088com

34 Tanus-Santos JE, Desai M, Deak LR, Pezzullo JC, Abernethy DR, Flockhart DA and Freedman JE: Effects of endothelial nitric oxide synthase gene polymorphisms on platelet function, nitric oxide release, and interactions with estradiol. Pharmacogenetics 12: 407-413, 2002. PMID: 12142730.

35 Godfrey V, Chan SL, Cassidy A, Butler R, Choy A, Fardon T, Struthers A and Lang C: The functional consequence of the Glu298Asp polymorphism of the endothelial nitric oxide synthase gene in young healthy volunteers. Cardiovasc Drug Rev 25: 280-288, 2007. PMID: 17919260. DOI: 10.1111/j.15273466.2007.00017.x

36 Wang J, Dudley D and Wang XL: Haplotype-specific effects on endothelial NO synthase promoter efficiency: modifiable by cigarette smoking. Arterioscler. Thromb Vasc Bio 22: e1-e4, 2002. PMID: 12006409.

37 Nakayama M, Yasue H, Yoshimura M, Shimasaki Y, Kugiyama $\mathrm{K}$, Ogawa H, Motoyama, T, Saito Y, Ogawa Y, Miyamoto Y and Nakao K: T-786- N C mutation in the 5'-flanking region of the endothelial nitric oxide synthase gene is associated with coronary spasm. Circulation 99: 2864-2870, 1999. PMID: 10359729.
38 Miyamoto Y, Saito Y, Nakayama M, Shimasaki Y, Yoshimura T, Yoshimura M, Harada M, Kajiyama N, Kishimoto I, Kuwahara K, Hino J, Ogawa E, Hamanaka I, Kamitani S, Takahashi N, Kawakami R, Kangawa K, Yasue H and Nakao K: Replication protein A1 reduces transcription of the endothelial nitric oxide synthase gene containing a -786T-NC mutation associated with coronary spastic angina. Hum Mol Genet 9: 2629-2637, 2000. PMID: 11063722. DOI: $10.1093 / \mathrm{hmg} / 9.18 .2629$

39 Zhang MX, Zhang C, Shen YH, Wang J, Li XN, Chen L, Zhang Y, Coselli JS and Wang XL: Effect of 27 nt small RNA on endothelial nitric-oxide synthase expression. Mol Biol Cell 19: 3997-4005, 2008. PMID: 18614799. DOI: 10.1091/mbc.e07-111186

40 Zhang, MX, Zhang C, Shen YH,Wang J, Li XN, Zhang Y, Coselli $\mathrm{J}$ and Wang XL: Biogenesis of short intronic repeat 27nucleotide small RNA from endothelial nitricoxide synthase gene. J Biol Chem 28: 14685-14693, 2008. PMID: 18390539. DOI: $10.1074 /$ jbc.M801933200

41 Silva PS, Lacchini R, Gomes VA and Tanus-Santos JE: Pharmacogenetic implications of the enos polymorphisms for cardiovascular action drugs. Arq Bras Cardiol 96(2): e27-e34, 2011. PMID: 21445464. DOI: 10.1590/s0066-782x20110002 00017

42 von Lueder TG and Krum H: RAAS inhibitors and cardiovascular protection in large scale trials. Cardiovasc Drugs Ther 27: 171179, 2013. PMID: 23224653. DOI: 10.1007/s10557-012-6424-y

43 Mentz RJ, Bakris GL, Waeber B, McMurray JJ, Gheorghiade M, Ruilope LM, Maggioni AP, Swedberg K, Pina IL and Fiuzat M: The past, present and future of renin-angiotensin aldosterone system inhibition. Int J Cardiol 167: 1677-1687, 2013. PMID: 23121914. DOI: $10.1016 /$ j.ijcard.2012.10.007

44 Linz W, Wohlfart P, Scholkens BA, Malinski T and Wiemer G: Interactions among ACE, kinins and NO. Cardiovasc Res 43: 549-561, 1999. PMID: 10690327. DOI: 10.1016/s0008-6363(99) 00091-7

45 Sandrim CA, Toledo CY, Desta Z, Flockhart DA, Moreno H and Tanus-Santos JE: Endothelial nitric oxide synthase haplotypes are related to blood pressure elevation, but not to resistance to antihypertensive drug therapy. J Hypertens 24: 2393-2397, 2006. PMID: 17082721. DOI: 10.1097/01.hjh.0000251899.47626.4f

46 Oliveira-Paula GH, Luizon MR, Lacchini R, Fontana V, Silva PS, Biagi $\mathrm{C}$ and Tanus-Santos JE: Gene-gene interactions among PRKCA, NOS3 and BDKRB2 polymorphisms affect the antihypertensive effects of enalapril. Basic Clin Pharmacol Toxicol 120: 284-291, 2017. PMID: 27696692. DOI: 10.1111/ bcpt.12682

47 Luizon MR, Palei ACT, Cavalli RC and Sandrim VC: Pharmacogenetics in the treatment of preeclampsia: current findings, challenges and perspectives. Pharmacogenomics 18(6): 571-583, 2017. PMID: 28358601. DOI: 10.2217/pgs-2016-0198

48 Ghiadoni L, Virdis A, Magagna A, Taddei S and Salvetti A: Effect of the angiotensin II type 1 receptor blocker candesartan on endothelial function in patients with essential hypertension. Hypertension 35: 501-506, 2000. PMID: 10642349.

49 Schiffrin EL, Park JB, Intengan HD and Touyz RM: Correction of arterial structure and endothelial dysfunction in human essential hypertension by the angiotensin receptor antagonist losartan. Circulation 101: 1653-1659, 2000. PMID: 10758046.

50 Schiffrin EL, Park JB and Pu Q: Effect of crossing over hypertensive patients from a beta-blocker to an angiotensin receptor antagonist on resistance artery structure and on 
endothelial function. J Hypertens 20: 71-78, 2002. PMID: 11791028.

51 Klingbeil AU, John S, Schneider MP, Jacobi J, Handrock R and Schmieder RE: Effect of AT 1 receptor blockade on endothelial function in essential hypertension. Am J Hypertens 16: 123-128, 2003. PMID: 12559678. DOI: 10.1016/s0895-7061(02)03154-0

52 Hornig B, Landmesser U, Kohler C, Ahlersmann D, Spiekermann S, Christoph A, Tatge $\mathrm{H}$ and Drexler $\mathrm{H}$ : Comparative effect of ACE inhibition and angiotensin II type 1 receptor antagonism on bioavailability of nitric oxide in patients with coronary artery disease: role of superoxide dismutase. Circulation 103: 799-805, 2001. PMID: 11171786.

53 Nickenig G and Harrison DG: The AT(1)-type angiotensin receptor in oxidative stress and atherogenesis: part I:oxidative stress and atherogenesis. Circulation 105: 393-396, 2002. PMID: 11804998.

54 Drexler $\mathrm{H}$ and Hornig B: Endothelial dysfunction in human disease. J Mol Cell Cardiol 31: 51-60, 1999. PMID: 10072715. DOI: $10.1006 / \mathrm{jmcc} .1998 .0843$

55 Mason RP and Cockcroft JR: Targeting nitric oxide with drug therapy. J Clin Hypertens 8: S40-S52, 2006. PMID: 17170605.

56 Thai H, Wollmuth J, Goldman S and Gaballa M: Angiotensin subtype 1 receptor (AT1) blockade improves vasorelaxation in heart failure by up-regulation of endothelial nitric-oxide synthase via activation of the AT2 receptor. J Pharmacol Exp Ther 307: 1171-1178, 2003. PMID: 14560036. DOI: 10.1124/jpet.103. 054916

57 Tsukada T, Yokoyama K, Arai T, Takemoto F, Hara S, Yamada A, Kawaguchi Y, Hosoya T and Igari J: Evidence of association of the ecNOS gene polymorphism with plasma NO metabolite levels in humans. Biochem Biophys Res Commun 245: 190-193, 1998. PMID: 9535806. DOI: 10.1006/bbrc.1998.8267

58 Wang XL, Mahaney MC, Sim AS,Wang J, Wang J, Blangero J, Almasy L, Badenhop RB and Wilcken DE: Genetic contribution of the endothelial constitutive nitric oxide synthase gene to plasma nitric oxide levels. Arterioscler Thromb Vasc Biol 17: 3147-3153, 1997. PMID: 9409304.

59 Bonnardeaux A, Nadaud S, Charru A, Jeunemaitre X, Corvol P and Soubrier F: Lack of evidence for linkage of the endothelial cell nitric oxide synthase gene to essential hypertension. Circulation 91: 96-102, 1995. PMID: 7528648.

60 Miyamoto Y, Saito Y, Kajiyama N, Yoshimura M, Shimasaki Y, Nakayama M, Kamitani S, Harada M, Ishikawa M and Kuwahara K: Endothelial nitric oxide synthase gene is positively associated with essential hypertension. Hypertension 32: 3-8, 1998. PMID: 9674630.

61 Li R, Lyn D, Lapu-Bula R, Oduwole A, Igho-Pemu P, Lankford B, Morgan J, Nkemdechi S, Liu G and Pack C: Relation of endothelial nitric oxide synthase gene to plasma nitric oxide level, endothelial function, and blood pressure in African Americans. Am J Hypertens 17: 560-567, 2004. PMID: 15233974. DOI: 10.1016/j.amjhyper.2004.02.013

62 Chen W, Srinivasan SR, Bond MG, Tang R, Urbina EM, Li S, Boerwinkle E and Berenson GS: Nitric oxide synthase gene polymorphism (G894T) influences arterial stiffness in adults: the Bogalusa Heart Study. Am J Hypertens 17: 553-559, 2004 PMID: 15233973. DOI: 10.1016/j.amjhyper.2004.02.021

63 Liljedahl U, Karlsson J and Melhus H: A microarray minisequencing system for harmacogenetic profiling of antihypertensive drug response. Pharmacogenetics 13(1): 7-17, 2003. PMID: 12544508
64 Pacanowski M, Zineh I, Cooper-DeHohh R, Pepine CJ and Johnson JA: Genetic and pharmacogenetic associations NOS3 polymorphisms, blood pressure, and cardiovascular events in hypertension. Am J Hypertens 22(7): 748-753, 2009. PMID: 19407804. DOI: 10.1038/ajh.2009.81

65 Pepine CJ, Handberg EM, Cooper-DeHoff RM, Marks RG, Kowey P, Messerli FH, Mancia G, Cangiano JL, Garcia-Barreto and Keltai M: INVEST Investigators: A calcium antagonist vs a non-calcium antagonist hypertension treatment strategy for patients with coronary artery disease. The International Verapamil-Trandolapril Study (INVEST): a randomized controlled trial. JAMA 290(21): 2805-2816, 2003. PMID: 14657064. DOI: 10.1001/jama.290.21.2805

66 Pasini AF, Garbin U, Stranieri C, Boccioletti V, Mozzini C, Manfro S, Pasini A, Cominacini $M$ and Cominacini L: Nebivolol treatment reduces serum levels of asymmetric dimethylarginine and improves endothelial dysfunction in essential hypertensive patients. Am J Hypertens 21: 1251-1257, 2008. PMID: 18772860. DOI: 10.1038/ajh.2008.260

67 Pasini AF, Garbin U, Nava MC, Stranieri C, Davoli A, Sawamura T, Lo Cascio V and Cominacini L: Nebivolol decreases oxidative stress in essential hypertensive patients and increases nitric oxide by reducing its oxidative inactivation. $\mathrm{J}$ Hypertens 23: 589-596, 2005. PMID: 15716701.

68 Chobanian AV, Bakris GL, Black HR, Cushman WC, Green LA, Izzo JL, Jr, Jones DW, Materson BJ, Oparil S, Wright JT Jr., Roccella EJ and The National High Blood Pressure Education Program Coordinating Committee: Seventh report of the Joint National Committee on Prevention, Detection, Evaluation, and Treatment of High Blood Pressure. Hypertension 42: 1206-1252, 2003. PMID: 14656957. DOI: 10.1161/01.HYP.0000 107251.49515.c2

69 Casas JP, Cavalleri GL, Bautista LE, Smeeth L, Humphries SE and Hingorani AD: Endothelial nitric oxide synthase gene polymorphisms and cardiovascular disease: a HuGE review. Am J Epidemiol 164: 921-935, 2006. PMID: 17018701. DOI: 10.1093/aje/kwj302

70 Zintzaras E, Kitsios G and Stefanidis I: Endothelial NO synthase gene polymorphisms and hypertension: a metaanalysis. Hypertension 48: 700-710, 2006. PMID: 16940230. DOI: 10.1161/01.HYP.0000238124.91161.02

71 Pereira TV, Rudnicki M, Cheung BM, Baum L, Yamada Y, Oliveira PS, Pereira AC and Krieger JE: Three endothelial nitric oxide (NOS3) gene polymorphisms in hypertensive and normotensive individuals: meta-analysis of 53 studies reveals evidence of publication bias. J Hypertens 25: 1763-1774, 2007. PMID: 17762636. DOI: 10.1097/HJH.0b013e3281de740d

72 Ding Y and Vaziri ND: Nifedipine and diltiazem but not verapamil up-regulate endothelial nitric-oxide synthase expression. J Pharmacol Exp Ther 292(2): 606-609, 2000. PMID: 10640297.

73 Taddei S, Virdis A and Ghiadoni L: Restoration of nitric oxide availability after calcium antagonist treatment in essential hypertension. Hypertension 37(3): 943-948, 2001. PMID: 11244022 .

74 Lenasi H, Kohlstedt K, Fichtlscherer B, Mulsch A and Busse $\mathrm{R}$ : Amlodipine activates the endothelial nitric oxide synthase by altering phosphorylation on Ser1177 and Thr495. Cardiovasc Res 59: 844-853, 2003. PMID: 14553824. DOI: 10.1016/s00086363(03)00505-4 
75 Zhang X, Lynch AI, Davis BR, Ford CE, Boerwinkle E, Eckfeldt $\mathrm{JH}$, Leiendecker-Foster C and Arnett DK: Pharmacogenetic association of NOS3 variants with cardiovascular disease in patients with hypertension: The GenHAT study. PLoS One 7(3): e34217, 2012. PMID: 22470539. DOI: 10.1371/journal.pone. 0034217

76 Turner ST, Chapman AB, Schwartz GL and Boerwinkle E: Effects of endothelial nitric oxide synthase, alpha-adducin, and other candidate gene polymorphisms on blood pressure response to hydrochlorothiazide. Am J Hypertens 16(10): 834-839, 2003. PMID: 14553962. DOI: 10.1016/s0895-7061(03)01011-2

77 Lacchini R and Tanus-Santos JE: Pharmacogenetics of erectile dysfunction: navigating into uncharted waters. Pharmocogenomics 15(11): 1519-1538, 2014. PMID: 25303302. DOI: 10.2217/ pgs.14.110

78 Di Salvatore M, Pietrantonio F, Orlandi A, Del Re M, Berenato R, Rossi E, Caporale M, Guarino D, Martinetti A and Basso M: IL-8 and eNOS polymorphisms predict bevacizumab-based first line treatment outcomes in RAS mutant metastatic colorectal cancer patients. Oncotarget 8(10): 16887-16898, 2017. PMID: 28129643. DOI: $10.18632 /$ oncotarget. 14810

79 Ando M: Nephrotoxicity - proteinuria and hypertension. Gan To Kagaku Ryoho 35: 1649-1653, 2008. PMID: 18931564.

80 Pande A, Lombardo J, Spangenthal E and Javle M: Hypertension secondary to anti-angiogenic therapy: Experience with bevacizumab. Anticancer Res 27: 3465-3470, 2007. PMID: 17972502.

81 Shubhangi A, Nibhriti D and Kamna S: Nitric oxide and eNOS gene in essential hypertension. IJCRIMPH 1(2): 56-71, 2009.

82 Souza-Costa DC, Sandrim VC, Lopes LF, Gerlach RF, Rego EM and Tanus-Santos JE: Anti-inflammatory effects of atorvastatin: modulation by the T-786C polymorphism in the endothelial nitric oxide synthase gene. Atherosclerosis 193: 438-444, 2007. PMID: 16938300. DOI: 10.1016/j.atherosclerosis.2006.07.020

83 Andrade VL, Sertório JT, Eleuterio NM, Tanus-Santos JE, Fernandes KS and Sandrim VC: Simvastatin treatment increases nitrite levels in obese women: modulation by $\mathrm{T}(-786) \mathrm{C}$ polymorphism of eNOS. Nitric Oxide 33: 83-87, 2013. PMID: 23876348. DOI: 10.1016/j.niox.2013.07.005

84 Jain MK and Ridker PM: Anti-inflammatory effects of statins: clinical evidence and basic mechanisms. Nat Rev Drug Discov 4: 977-987, 2005. PMID: 16341063. DOI: 10.1038/nrd1901

85 Tamai O, Matsuoka H, Itabe H, Wada Y, Kohno K and Imaizumi T: Single LDL apheresis improves endothelium-dependent vasodilatation in hypercholesterolemic humans. Circulation 95: 76-82, 1997. PMID: 8994420.

86 Anderson TJ, Meredith IT, Yeung AC, Frei B, Selwyn AP and Ganz P: The effect of cholesterol-lowering and antioxidant therapy on endothelium-dependent coronary vasomotion. New Engl J Med 332: 488-493, 1995. PMID: 7830729. DOI: 10.1056/ NEJM199502233320802

87 Treasure CB, Klein JL, Weintraub WS, Talley JD and Stillabower ME: Beneficial effects of cholesterol-lowering therapy on the coronary endothelium in patients with coronary artery disease. New Engl J Med 332: 481-487, 1995. PMID: 7830728. DOI: 10.1056/NEJM199502233320801

88 O'Driscoll G, Green D and Taylor RR: Simvastatin, an HMGcoenzyme A reductase inhibitor, improves endothelial function within 1 month. Circulation 95: 1126-1131, 1997. PMID: 9054840.

89 Laufs U, Fata VL and Liao JK: Inhibition of 3-hydroxy-3methylglutaryl (HMG)-CoA reductase blocks hypoxia-mediated down-regulation of endothelial nitric oxide synthase. J Biol Chem 272: 31725-31729, 1997. PMID: 9395516. DOI: 10.1074/ jbc.272.50.31725

90 Searles CD: Transcriptional and posttranscriptional regulation of endothelial nitric oxide synthase expression. Am J Physiol Cell Physiol 291: C803-C816, 2006. PMID: 16738003. DOI: 10.1152/ ajpcell.00457.2005

91 Oliveira-Paula GH, Lacchini R and Tanus-Santos JE: Endothelial nitric oxide synthase: From biochemistry and gene structure to clinical implications of NOS3 polymorphisms. Gene 575(2): 584599, 2016. PMID: 26428312. DOI: 10.1016/j.gene.2015.09.061

92 Kosenko E, Tikhonova L and Suslikov A: Impacts of lisinopril and lisinopril plus simvastatin on erythrocyte and plasma arginase, nitrite, and nitrate in hypertensive patients, J Clin Pharmacol 52: 102-109, 2012. PMID: 21406601. DOI: 10.1177/0 091270010388647

93 Nakashima, Toyokawa Y and Tanaka S: Simvastatin increases plasma $\mathrm{NO}_{2}$ - and $\mathrm{NO}_{3}$ - levels in patients with hypercholesterolemia, Atherosclerosis 127: 43-47, 1996. PMID: 9006803.

94 Laufs U, La Fata V, Plutzky J and Liao JK: Upregulation of endothelial nitric oxide synthase by HMG CoA reductase inhibitors. Circulation 97(12): 1129-1135,1998. PMID: 9537338.

95 Kureishi Y, Luo Z, Shiojima I, Bialik A and Fulton D: The HMGCoA reductase inhibitor simvastatin activates the protein kinase Akt and promotes angio-genesis in normocholesterolemic animals. Nat Med 6: 1004-1010, 2000. PMID: 10973320. DOI: 10.1038/79510

96 Sumi D, Hayashi T, Thakur NK, Jayachandran M, Asai Y and Kano H: A HMGCoA reductase inhibitor possesses a potent antiatherosclerotic effect other than serum lipid lowering effects--the relevance of endothelial nitric oxide synthase and superoxide anion scavenging action. Atherosclerosis 155(2): 347-357, 2001. PMID: 11254905

97 Liao JK: Clinical implications for statin pleiotropy. Curr Opin Lipidol 16: 624-629, 2005. PMID: 16276239.

98 Habara K, Hamada Y, Yamada M, Tokuhara K, Tanaka H, Kaibori M, Kamiyama Y, Nishizawa M, Ito S and Okumura T: Pitavastatin up-regulates the induction of iNOS through enhanced stabilization of its mRNA in pro-inflammatory cytokinestimulated hepatocytes. Nitric Oxide 18(1): 19-27, 2008. PMID: 17936042. DOI: 10.1016/j.niox.2007.08.005

99 Brouet A, Sonveaux P, Dessy C, Moniotte S, Balligand JL and Feron O: Hsp90 and caveolin are key targets for the proangiogenic nitric oxide-mediated effects of statins. Circ Res 89: 866-873, 2001. PMID: 11701613.

100 Plenz GA, Hofnagel O and Robenek H: Differential modulation of caveolin-1 expression in cells of the vasculature by statins. Circulation 109: e7-e8, 2004. PMID: 14734510. DOI: 10.1161/01.CIR.0000111128.83347.7A

101 Takemoto M and Liao JK: Pleiotropic effects of 3-hydroxy-3methylglutaryl coenzyme a reductase inhibitors. Arterioscler Thromb Vasc Biol 21(11): 1712-1719, 2001. PMID: 11701455.

102 Kunnas TA, Lehtimaki T, Laaksonen R, Ilveskoski E, Janatuinen $\mathrm{T}$ and Vesalainen R: Endothelial nitric oxide synthase genotype modulates the improvement of coronary blood flow by pravastatin: a placebo-controlled PET study. J Mol Med 80(12): 802-807, 2002. PMID: 12483466. DOI: 10.1007/s00109-002-0398-3

Received February 21, 2019

Revised June 9, 2019

Accepted June 19, 2019 